R. História, Sño Paulo, n. 125-126, p. 149-192, ago-tez/91 a jan-jul/92.

\author{
PHILLIPS, William D., PHILLIPS, Carla Rahn. The Worlds of C'hristopher \\ Columbus. Cambridge: Cambridge University Press, 1992. Maps. Dra- \\ wings. Index. Bibliography, $322 \mathrm{p}$.
}

\title{
Michael LaRosa*
}

With the quincentenary, this book is not only timely but appropriate in that it dispels many of the myths surroundig Columbus and helps place him in the context of fifteenth century Europe and America. As the title ingeniously suggests, there are many worlds for Columbus - in Italy, Portugal, Spain and America - and a scholarly synthesis of all these worlds helps the reader to understand more fully Columbus's objectives, achievements, shortcomings, and mistakes.

Written in a crisp style and beautifully illustrated throughout, The Worlds of Christopher Columbus is designed to attract the scholar not only as part-time historian, but also the nonspecialist reader. At the outset, the authors insist that the only way Columbus can be properly studied is through a thorough process of de-mythification. In the United States, Columbus gained hero status with Washington Irving's The Life and Voyages of C/hristopher Columbus in 1828. Irving extolled Columbus's virtues of courage, intelligence, and patience in a narrative form and since then. the explorer has been uncritically lauded as a Renaissance man of great learning and scientific ability. Columbus was a scientist of sorts: he used a technique known as "dead reckoning" to guide him across the ocean. This method combined observation with the measurement of time, speed, and direction; such information was carefully recorded by Columbus, and calculations were made to determine location. After four trans-Atlantic voyages he still failed to find the sought after gold, spices and silks of the Far East while insisting that he had explored a peninsula which was just east of the Far East. He relied on data suggesting that the circumference of the earth was smaller than we know it to be. Based on his calculations, a straight-shot west - from the Canary Islands - with good wind would put one in the Far East in about $\mathbf{3 0}$ days. Columbus set sail from the Canary Islands on 6 September 1492 and when a

\footnotetext{
* Departamento de História University of Miami.
} 
small island in the Bahamas was sighted on 12 October Columbus assumed he had reached the Far East. Columbus's views on religion were far from scientific and belonged more to the medieval world rather than that of the skeptical Renaissance. His own writings suggest that some of the "revenue" which would hopefully be generated from his expeditions might to toward financing a new crusade to free the Holy Land from the grip of Islam. Although the authors are reporting nothing new - John Leddy Phelan described this situation in 1956 in his The Millennial Kingdom of the Franciscans in the New World - their careful review enables the reader to evaluate Columbus on the basis of existing documentation rather than rhetoric.

Columbus did not hesitate to enslave the Native American population, despite objections from the crown which sought protection for its "subjects". The issue of slavery grew increasingly divisive for Columbus and his benedactors, Ferdinand and Isabela, and Columbus cleverly resorted to the effective, medieval concept of "just war" to enslave the Indians by claiming that the Native Americans were in fact at war against the Europeans and thus deserved slavery rather than protection. The Dominican priest Bartolomé de las Casas was a determinated opponent to this pretense for slavery; the authors however seem to discount the importance of this work. Las Casas's writings served to denounce Spanish practices in the Americas, and were the first attempt to catalogue and champion Native American society and culture. Although flawed by twentieth-century standards of objective historical scholarship, these writings could have been used more creatively by the authors as they constitute the most "ethnographic" primary source available on Native American society at the time of contact.

Columbus did not always tell the truth. At times, he reported information to the King and Queen that he could not verify with absolute certainty. His initial description of the Native Americans placed them in the realm of some sort of unknown paradise, now made known thanks to his own efforts. Declaring his mission a success and seeking increased funding and recognition from the Crown, Columbus reported the native Americans as, "have(ing) the sweetest speech in the world; and (they are) gentle and are always laughing. They go about as naked, men and women, as their mothers bore them, but many Your Highnesses believe that among themselves they have very good customs" (p. 173). As tensions mounted between Europeans and Native Americans, Columbus's description of the natives changed. In 1500 these same gentle people are described as "warlike and numerous, and with customs and beliefs very different from ours" (p. 277). Columbus also misled the King and Queen with respect to the quantity of Caribbean riches.

Columbus was inept at and not interested the day to day administrative functions of developing a settled colony. This created tensions between 
himself and the Crown and many others including his crew, settlers on the island of Hispañiola (today comprised of the Dominican Republic and Haiti) and Natives. His impatience with administration led to rash, ad-hoc decisions in the distribution of labor. Thus, an institution which divided up Indian labor (encomienda) was established during this time and became accepted practice. The inequalities inherent in this system laid the foundation for an American caste system and centuries of economic activity characterized by booms and busts rather than steady growth and development.

The Phillips' are remarkably comprehensive and clearly command the literature that pertains to both sides of the Atlantic. Though they seem more comfortable with the European world of Columbus, the authors devote the last four chapters of the book to the Americas and skillfully deal with complex and currently studied issues. Such issues include disease and demographic collapse, labor systems and supply, exchange of products and the evolving system of administrating, from Madrid, a large overseas empire.

The arrival of the Europeans in America meant an exchange of agricultural products, animals and diseases. Wheat, oats, horses, pigs, smallpox, and measles went from east to west and the potato, maize, lobacco, turkeys and syphilis travelled to Europe. The European diseases claimed the lives of millions of Native Americans during the sixteenth century and the authors carefully examine the existing literature of Borah, Cook and Denevan to evaluate this dramatic demographic collapse. The Phillips' argue that Spaniards did not intend genocide since they needed live native for purposes of labor and religious conversion. Still, forced labor practices and destruction of Native American communities created stress and made natives more susceptible to disease. This demographic collapse is the most controversial issue surrounding the voyages of Columbus and the subsequent contact between Europeans and Native Americans. The autors present the details of this destruction as recorded in primary and secondary sources in a clear, scientific and non-judgmental manner. Ultimately, this benefits the reader who can make up her on mind based on the author's synthesis.

The Worlds of C./hristopher Columbus is a timely and important contribution. Far more than a biography of an explorer, this book places Columbus in a variety of locales during a period of great transition, both in Europe and America. Through a careful analysis of primary texts, Columbus is humanized and this results in a clear and sophisticated piece of scholarship. A complex man, Columbus comes across as egotistical, politically sophisticated and scientifically adroit. The Phillips' work will be appealing to a wide variety of audiences and provides an important foundation for more in-depth research and reading on subjects ranging from religion, economic history, slavery, Spanish history and Native American civilizations. 